\title{
THE STUDY OF THE FOAMING ABILITY OF SOME SURFACTANTS
}

\author{
A.O.Drozdova \\ National Medical Academy of Postgraduate Education named after P.L. Shupyk \\ Key words: surfactants; foaming ability; stability and height of the foam
}

\begin{abstract}
The foaming ability of some surfactants, namely such parameters as the height of the foam column and foam stability, has been studied. It has been found that in solutions with one surfactant there is no specific dependence between the foam height and foam stability. It has been proven experimentally that the active phase of foaming (the height of the foam column) lasts up to 100-150 s. Starting from $150 \mathrm{~s}$ the height of the foam decreases, and this process lasts up to $300 \mathrm{~s}$. It has been shown that despite the fact that the surfactants studied form foam in solutions, there is no possibility to select the optimal surfactant. According to the studies conducted it is due to the fact that a stable foam is formed by combining two or more surfactants. The data obtained show that the test solutions are not suitable for use in the drug composition because it is impossible to guarantee the quality of the foam. Therefore, to ensure the quality of foam-forming composition it is rational to continue further studies of the combination of two or more surfactants in solutions.
\end{abstract}

Natural and synthetic surfactants are an essential component in the foaming compositions. The ability to absorption at the interphase boundary and aggregation in the bulk solution is significant for each surfactant $[6,7]$. Adsorbing at interfaces and forming micelles the surfactants contribute to dissolution, emulsification, foaming and some other processes that occur in solutions [4].

Along with the surface activity of the surfactant itself, the foaming ability of a surfactant is characterized by the mechanical strength and viscosity of the films formed $[2,4,6]$.

Methods for determining the ability of the foaming ability can be divided into static and dynamic although this division is rather conventional; and taking into account the equipment used in the studies in some cases there is no difference between these methods $[5,6]$. Determination by dynamic methods is carried out under continuous mechanical action on the solution to prevent the possibility of running off the foam from it $[3,5]$. Under dynamic conditions the volume of the foam measured is determined by the ratio between the rate of its formation and its destruction, and the volume of foam under static conditions is dependent on the speed of bubbles dissolution. The foaming ability of surfactant solutions is the characteristic that must be considered when developing foam formulations. This is due to the fact that formation of a stable foam is a guarantee of quality of the foam formulation.

The aim of this study was to investigate the foaming ability of some surfactants determining such indicators as the height of the foam column and foam stability.

\section{Materials that Methods}

The foaming ability of the surfactant solutions was determined on a Ross-Miles device at $50 \pm 2^{\circ} \mathrm{C}$ according to the GOST 22567.1-77 [1].
The objects of the study were such surfactants as sodium lauryl sulfate, emulsifier No.1, OC 20 (macrogol cetostearyl ester), polysorbate 80 , sorbitan laurate, sodium docusate, PEG 6 stearate (glycol stearate), sucrose palmitate, PEG 75 stearate (cetyl alcohol (and) glyceryl stearate), cocamidopropylbetaine, PEG 100 stearate (glyceryl stearate and PEG 100 stearate), glyceryl laurate, distilled monoglycerides, wax emulsion, dodecyl dipropylene triamine, polysorbate 20, dodecyl-dimethyl ammonium chloride, polyhexamethyleneguanidine, miramistin.

Test solutions were prepared with the surfactant concentration of $7 \%$.

\section{Results and Discussion}

Fig. 1 (A, B, C, D) presents the results of our studies in the form of a graphical dependence of the height of the foam column on time ( $300 \mathrm{~s})$.

A comparative analysis of the data in Fig. 1 shows that the indicator of the height of the foam column of such surfactants as PEG 6 stearate, PEG 75 stearate, PEG 100 stearate, wax emulsion, emulsifier No.1, distilled monoglycerides, sucrose palmitate and glyceryl laurate is inferior to the height of the foam column of such surfactants as sodium lauryl sulfate, OC 20, polysorbate 80 , sorbitan laurate, sodium docusate, cocamidopropylbetaine, dodecyl dipropylene triamine, polysorbate 20, dodecyl-dimethyl ammonium chloride, polyhexamethyleneguanidine and miramistin. The active phase of foaming (the height of the foam column) lasts up to $100-150 \mathrm{~s}$. Starting from $150 \mathrm{~s}$ the height of the foam decreases, and this process lasts up to $300 \mathrm{~s}$.

When developing a drug the indicator of the foam stability is also an important characteristic because, in our opinion, it directly affects the therapeutic activity of the drug. Fig. 2 shows the results of the study of the foam stability of the surfactants mentioned above. 


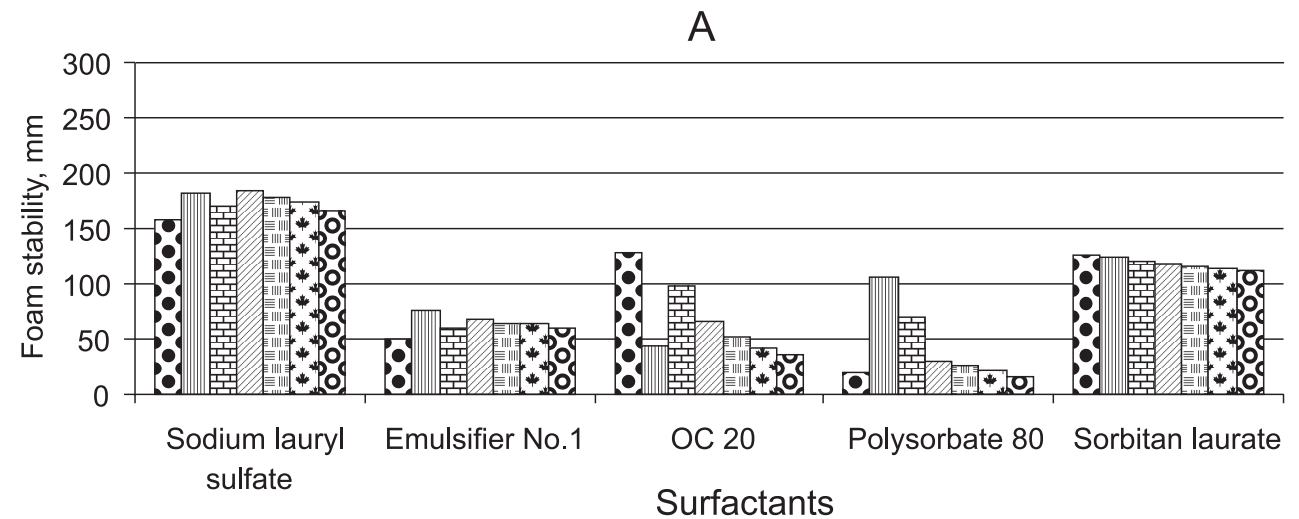

B

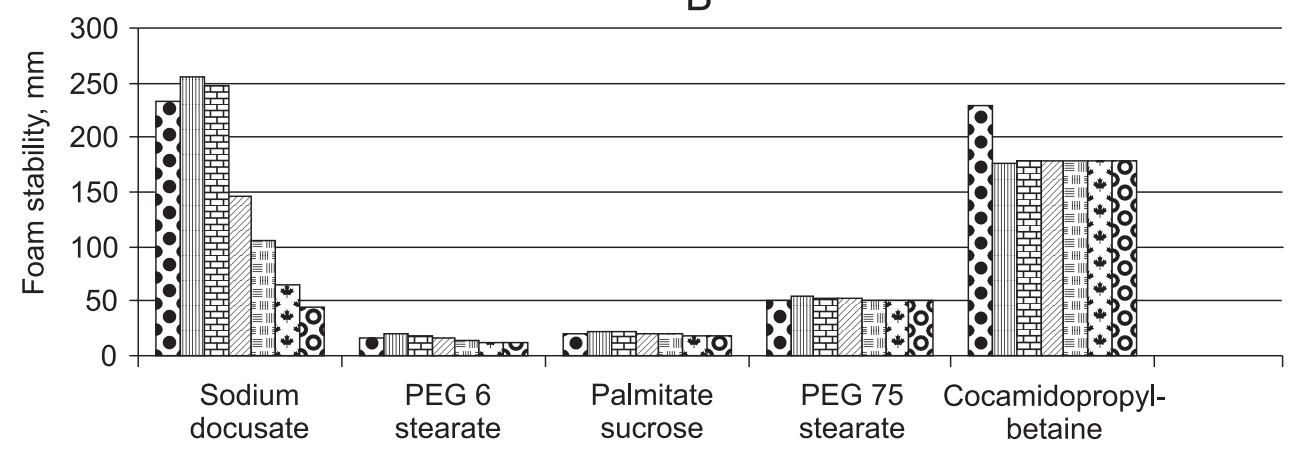

Surfactants

C

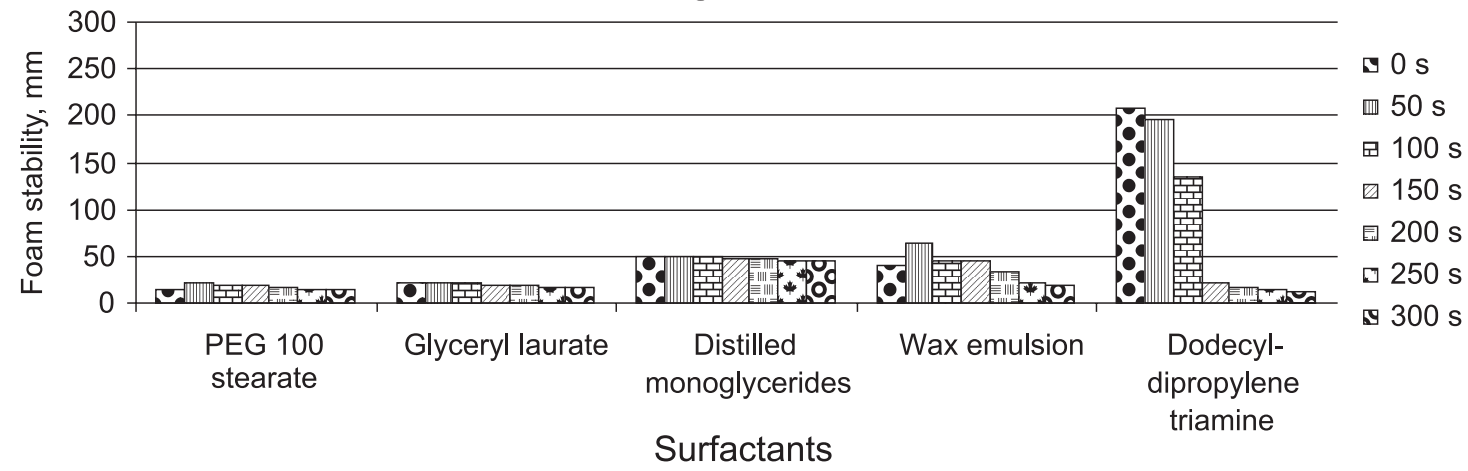

D

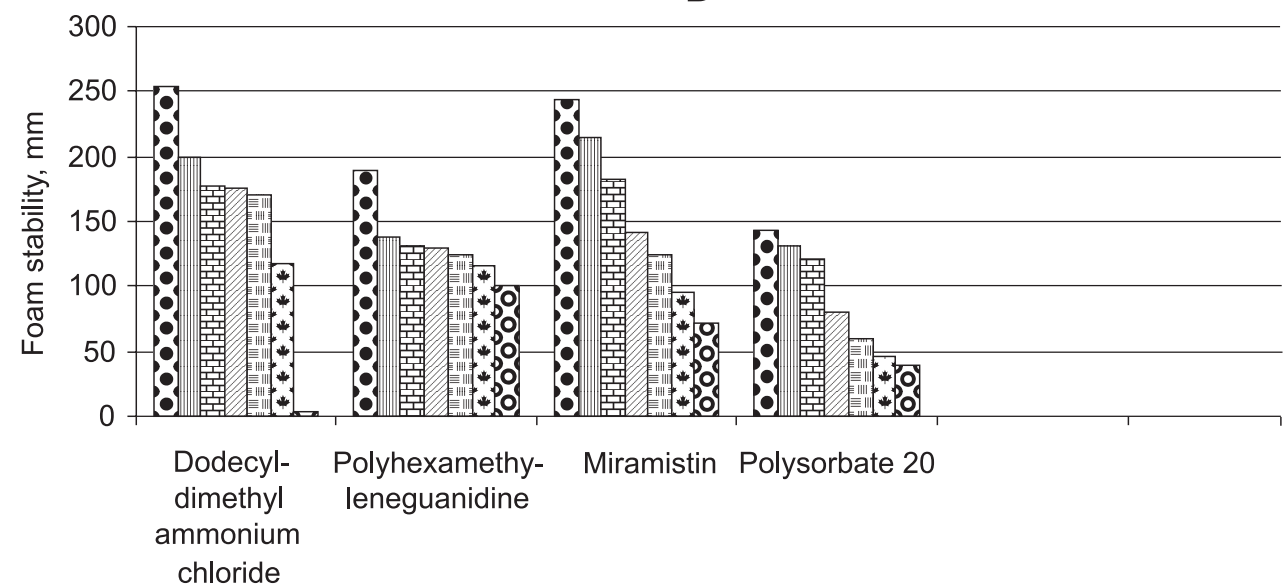




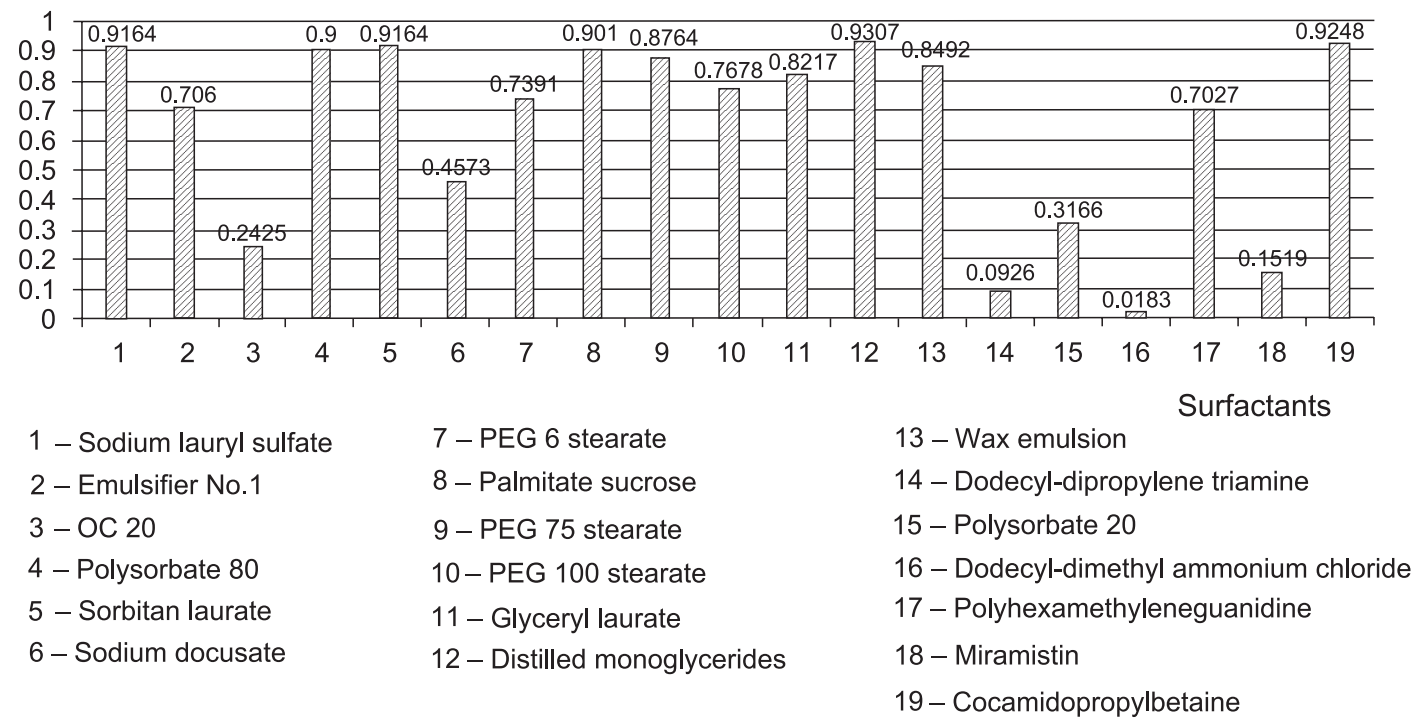

Fig. 2. Stability of the surfactant foam.

It has been found experimentally that sodium lauryl sulfate, emulsifier No.1, polysorbate 80 , sorbitan laurate, PEG 6 stearate, sucrose palmitate, PEG 75 stearate, cocamidopropylbetaine, PEG 100 stearate, glyceryl laurate, distilled monoglycerides, wax emulsion and polyhexamethyleneguanidine form a stable foam. It should be noted that there is no direct relationship between the height of the foam and its stability.

\section{CONCLUSIONS}

The data obtained show that despite the fact that the surfactants studied form foam in solutions, there is no possibility to select the optimal surfactant. According to the studies previously conducted a stable foam is formed by combining two or more surfactants; therefore, foamforming properties of mixtures of hydrophilic and hydrophobic surfactants will be studied in future.

\section{REFERENCES}

1. Средства моющие синтетические. Метод определения пенообразующей способности: ГОСТ 22567.1-77 (СТ СЭВ 4155-83). - [Взамен ГОСТ 22567.1-77]. - Введ. 01.05.86. - М.: Изд-во стандартов, 1986. - С. 1-6.

2. Холмберг К., Йёнссон Б., Кронберг Б., Линдман Б. Поверхностно-активные вещества и полимеры 8 водных растворах. - М.: БИНОМ. Лаборатория знаний, 2007. -528 c.

3. Langevin D. // Adv. Colloid Interface Sci. - 2000. - Vol. 88. - P. 209-222.

4. Lunkenheimer K., Malysa K., Winsel K. et al. // Langmuir. - 2010. - Vol. 26. - P. 3883-3888.

5. Russev S.C., Alexandrov N., Marinova K.G. // Rev. Sci. Instr. - 2008. - Vol. 79. - P. 102-104.

6. Stubenrauch C., Fainerman V.B. // J. Phys. Chem. B. - 2005. - Vol. 109. - P. 1505-1509.

7. Stubenrauch C., Khristov Kh. // J. Colloid Interface Sci. - 2005. - Vol. 286. - P. 710-718.

\section{ДОСЛІДЖЕННЯ ПІНОУТВОРЮЮЧОЇ ЗДАТНОСТІ ДЕЯКИХ ПОВЕРХНЕВО-АКТИВНИХ РЕЧОВИН \\ А.О.Дроздова \\ Ключові слова: поверхнево-активні речовини; піноутворююча здатність; стійкість i висота піни}

Вивчена піноутворююча здатність деяких поверхнево-активних речовин, а саме такі їх показники як висота стовпа та стійкість піни. Встановлено, що в розчинах, які містять одну поверхнево-активну речовину, не існує певної залежності між висотою піни і їі стійкістю. Експериментально доведено, що активна фраза піноутворення (висота стовпа піни) триває 100-150 с. Починаючи з 150 с, висота стовпа піни зменшується, а даний процес продовжується до 300 с. Показано, що досліджувані поверхнево-активні речовини в розчинах хоча і утворюють піну, але обрати оптимальну поверхнево-активну речовину неможливо. Це пов'язано з тим, що стійка піна, згідно з проведеними дослідженнями, утворюється при поєднанні двох $і$ більще поверхнево-активних речовин. Отримані дані свідчать про те, що досліджувані розчини не придатні для використання в складі препарату, так як неможливо гарантувати якість піни. Тому доцільно подальше вивчення сумішей двох і більше поверхнево-активних речовин у розчинах для гарантованої якості піноутворюючого складу. 
ИССЛЕДОВАНИЕ ПЕНООБРАЗУЮЩЕЙ СПОСОБНОСТИ НЕКОТОРЫХ ПОВЕРХНОСТНОАКТИВНЫХ ВЕЩЕСТВ

\section{А.А.Дроздова}

Ключевые слова: поверхностно-активные вещества; пенообразующая способность; устойчивость и высота пены

Изучена пенообразующая способность некоторых поверхностно-активных веществ, а именно такие показатели как высота столба пены и устойчивость пены. Установлено, что в растворах с одним поверхностно-активным веществом нет зависимости между высотой пены и ее устойчивостью. Экспериментально доказано, что активная фраза пенообразования (высота столба пены) продолжается до 100-150 с. Начиная с 150 с, высота столба пены уменьшается, а данный процесс длится до 300 с. Показано, что исследуемые поверхностно-активные вещества в растворах хотя и образуют пену, но выбрать оптимальное поверхностно-активное вещество не представляется возможным. Это связано с тем, что стойкая пена, согласно проведенным исследованиям, образуется при сочетании двух и больше поверхностно-активных веществ. Полученные данные свидетельствует о том, что исследуемые растворы не пригодны для использования в составе препарата, так как невозможно гарантировать качество пены. Поэтому целесообразно дальнейшее изучение сочетания двух и более поверхностно-активных веществ в растворах для гарантированного качества пенообразующего состава. 